\title{
PELATIHAN PENYUSUNAN RPP TEMATIK INTEGRATIF MENGGUNAKAN PENDEKATAN SAINTIFIK BAGI GURU-GURU SEKOLAH DASAR GUGUS VIII ABIANSEMAL BADUNG TAHUN PELAJARAN 2015/2016
}

\author{
Semara Putra4. I Gusti Agung Ayu Wulandari 5. \\ 1 Jurusan Pendidikan Guru Sekolah Dasar. Universitas Pendidikan Ganesha, Indonesia \\ 2 Jurusan Pendidikan Guru Sekolah Dasar. Universitas Pendidikan Ganesha, Indonesia \\ 3 Jurusan Pendidikan Guru Sekolah Dasar. Universitas Pendidikan Ganesha, Indonesia \\ ${ }^{4}$ Jurusan Pendidikan Guru Sekolah Dasar. Universitas Pendidikan Ganesha, Indonesia \\ 5 Jurusan Pendidikan Guru Sekolah Dasar. Universitas Pendidikan Ganesha, Indonesia
}

I Nengah Suadnyana1, ${ }^{*}$, I Komang Ngurah Wiyasa², I Ketut Ardana ${ }^{3}$, DB. KT NGR.

\begin{abstract}
Abstrak
Pengabdian pada masyarakat ini bertujuan untuk meningkatkan pemahaman dan keterampilan guru dalam menyusun RPP Tematik Integratif dengan menggunakan pendekatan saintifik. Kegiatan ini dilakukan melalui pelatihan penyusunan RPP menggunakan pendekatan saintifik. Data dikumpulkan dengan menggunakan metode observasi yang kemudian dianalisis menggunakan metode analisis deskriptif kualitatif. Hasil kegiatan pengabdian masyarakat ini menunjukkan bahwa peserta sangat antusias mengikuti pelatihan sehingga dapat menyelesaikan semua tugas yang diberikan. Ada 6 RPP tematik integratif menggunakan pendekatan saintifik sebagai hasil kegiatan pelatihan. Dengan demikian, kegiatan ini dapat meningkatkan kemampuan dan keterampilan guru-guru dalam menyusun RPP pembelajaran tematik terpadu dengan pendekatan saintifik dan secara real dapat membantu guruguru untuk menyusun RPP tematik integratif dengan pendekatan saintifik sesuai dengan kurikulum 2013 di SD Gugus VIII Abiansemal Badung.
\end{abstract}

\author{
Keywords: \\ Model pembelajaran \\ kooperatif tipe \\ Numbered Heads \\ Together, hasil belajar
}

\section{Pendahuluan}

Pendidikan merupakan suatu usaha sadar dan terencana untuk mewujudkan suasana belajar melalui proses pembelajaran yang memungkinkan peserta didik secara aktif mengembangkan seluruh potensi pada dirinya sehingga mampu memiliki kekuatan spiritual keagamaan, pengendalian diri, kecerdasan, akhlak mulia, serta keterampilan-keterampilan yang diperlukan oleh dirinya, masyarakat, bangsa dan negara. Untuk itu dibutuhkan tenaga-tenaga pendidik profesional yang mampu merancang proses pembelajaran sesuai dengan rambu-rambu yang ditetapkan dalam Standar Proses Pendidikan untuk mencapai Standar Kompetensi Lulusan.Standar Proses mencakup perencanaan proses pembelajaran, pelaksanaan proses pembelajaran, penilaian hasil pembelajaran, dan pengawasan proses pembelajaran (Mendikbud, 2013). Merencanakan proses pembelajaran menjadi tugas guru yang sangat penting karena hal ini merupakan awal proses yang menentukan berhasil tidaknya proses pembelajaran yang akan dilaksanakan oleh guru. Dengan menyusun Rencana Pelaksanaan Pembelajaran (RPP) yang baik maka kegiatan selanjutnya dapat berjalan dengan baik. Rencana Pelaksanaan Pembelajaran dikembangkan sesuai dengan karakteristik kompetensi pada Standar Kompetensi Lulusan yang mencakup pengembangan ranah sikap, pengetahuan, dan keterampilan. Ketiga ranah kompetensi ini dalam proses pembelajaran dikembangkan secara utuh dan tidak bisa dipisahkan satu dengan yang lainnya walaupun perolehannya melalui pengalaman belajar yang berbeda. Pembelajaran di Sekolah Dasar (SD) menggunakan pembelajaran tematik terpadu dengan pendekatan ilmiah artinya pembelajaran tematik 
antarmata pelajaran yang didasari oleh proses penemuan/penelitian (discovery/inquiry). Dalam hal ini pemilihan tema, model, pendekatan, dan materi ajar disesuaikan dengan tingkat perkembangan siswa SD yang berada pada tahap operasional konkret. Hal-hal nyata yang ada di lingkungan sehari-hari (kontekstual) sangat cocok dijadikan tema/subtema, karena dapat memudahkan siswa membangun pengetahuan baru melalui konsepsi-konsepsi awal mereka. Hal ini sejalan dengan pendapat Nurhadi (2003) yang menyatakan bahwa proses pembelajaran hendaknya berlangsung secara alamiah dalam bentuk kegiatan siswa bekerja dan mengalami, bukan transfer pengetahuan dari guru ke siswa.

Pada implementasi kurikulum 2013, Rancangan Pembelajaran Tematik Terpadu untuk siswa SD sudah disiapkan dalam bentuk silabus, buku guru dan buku siswa. Dalam silabus telah ditentukan kompetensi inti, kompetensi dasar, tema dan subtema, materi pokok, kegiatan pembelajaran, penilaian, alokasi waktu, dan sumber belajar. Karena itu sebagian besar rencana pembelajaran telah diseting dari pusat sehingga perlu ada usaha guru untuk mengembangkan RPP tersebut agar memiliki nuansa lokal khususnya Budaya Bali yang sesuai dengan konteks keseharian siswa SD di Denpasar Selatan.

Pembelajaran tematik sudah mulai diterapkan di SD sejak berlakunya Kurikulum 2004, namun penerapannya di lapangan belum memenuhi harapan. Pemahaman tentang pembelajaran Tematik di kalangan guru masih bervariasi sehingga menimbulkan perbedaan dalam penyusunan RPP maupun pelaksanaan proses pembelajarannya. Perubahan pada Standar Nasional Pendidikan telah tertuang dalam peraturan Pemerintah No. 32 tahun 2013 yang memberikan arahan tentang perlunya disusun dan dilaksanakan delapan standar nasional pendidikan yaitu standar isi, standar proses, standar kompetensi lulusan, standar pendidikan dan tenaga kependidikan, standar sarana dan prasarana, standar pengelolaaan, standar pembiayaan, dan standar penilaian pendidikan. Walaupun berbagai upaya telah dilakukan pemerintah untuk meningkatkan kualitas hasil pembelajaran, baik melalui penataran guru, seminar, KKG, lokakarya maupun program sertifikasi guru, namun masih banyak ditemukan guru yang tidak melaksanakan pembelajaran tematik terpadu. Dengan kata lain pembelajaran masih berorientasi pada mata pelajaran seperti matematika, IPA dan lain sebagainya.

Penerapan kurikulum 2013 kususnya di Provinsi Bali sudah dilaksanakan secara menyeluruh di Kota Denpasar, dan sebagian sekolah di kecamatan lain sebagai percontohan. Sekolah-sekolah yang belum tersentuh Kurikulum 2013 perlu diperhatikan bila perlu diberikan pelatihan tentang bagaimana penerapan kurikulum 2013, sekolah-sekolah tersebut diantaranya Gugus VIII Abiansemal Badung. Secara umum kondisi fisik sekolah-sekolah di gugus VIII Abiansemal bisa dikatakan cukup memadai namun masih ada beberapa aspek yang perlu diperhatikan seperti; kondisi lingkungan yang gersang dan kurang hijau, serta ketersediaan media pembelajaran yang kurang. Kualifikasi guru di gugus VIII Abiansemal sebagaian besar sudah tersertifikasi ini artinya guru-guru tersebut seharusnya mampu melaksanakan dan mengikuti perubahan kurikulum yang ada. Berdasarkan analisis situasi maka dapat diidentifikasi masalah sebagai berikut.

a. Guru-guru masih belum bisa melakukan pembelajaran Tematik dengan baik untuk kelas rendah

(kelas1,2,3).

b. Sebagian besar guru belum memperoleh pelatihan tentang implementasi kurikulum 2013.

c. Failitas sekolah untuk mendapatkan informasi tentang Kurikulum 2013 belum memadai

Mengacu pada identifikasi masalah, maka dapat dirumuskan masalah sebagai berikut. Setelah dilaksanakan pelatihan diharapkan terjadi perubahan pemahaman dan keterampilan guru dalam menyusun RPP Tematik Integratif dengan menggunakan pendekatan saintifik.

Adapun tujuan kegiatan ini adalah sebagai berikut.

Untuk meningkatkan kemampuan dan keterampilan guru-guru Gugus VIII Abiansemal dalam menyusun RPP dan melaksanakan pembelajaran tematik terpadu dengan menggunakan pendekatan saintifik.

\section{Metode}

Kerangka pemecahan masalah untuk meningkatkan kemampuan guru-guru Gugus VIII Abiansemal dalam menyusun RPP tematik integratif menggunakan pendekatan saintifik yang menekankan pada lima kegiatan pengalaman belajar pokok, yaitu mengamati, menanya, menalar, mengasosiasi, dan mengkomunikasikan. Kegiatan ini dilakukan dalam bentuk pelatihan melalui langkahlangkah sebagai berikut.

Secara skematis langkah-langkah pemecahan masalah didiagramkan sebagai berikut: 


\section{Permasalahan Utama:}

1. Guru-guru masih belum bisa melakukan pembelajaran Tematik dengan baik untuk kelas rendah (kelas1,2,3).

2. Sebagian besar guru belum memperoleh pelatihan tentang implementasi kurikulum 2013

3. Failitas sekolah untuk mendapatkan informasi tentang Kurikulum 2013 belum memadai.

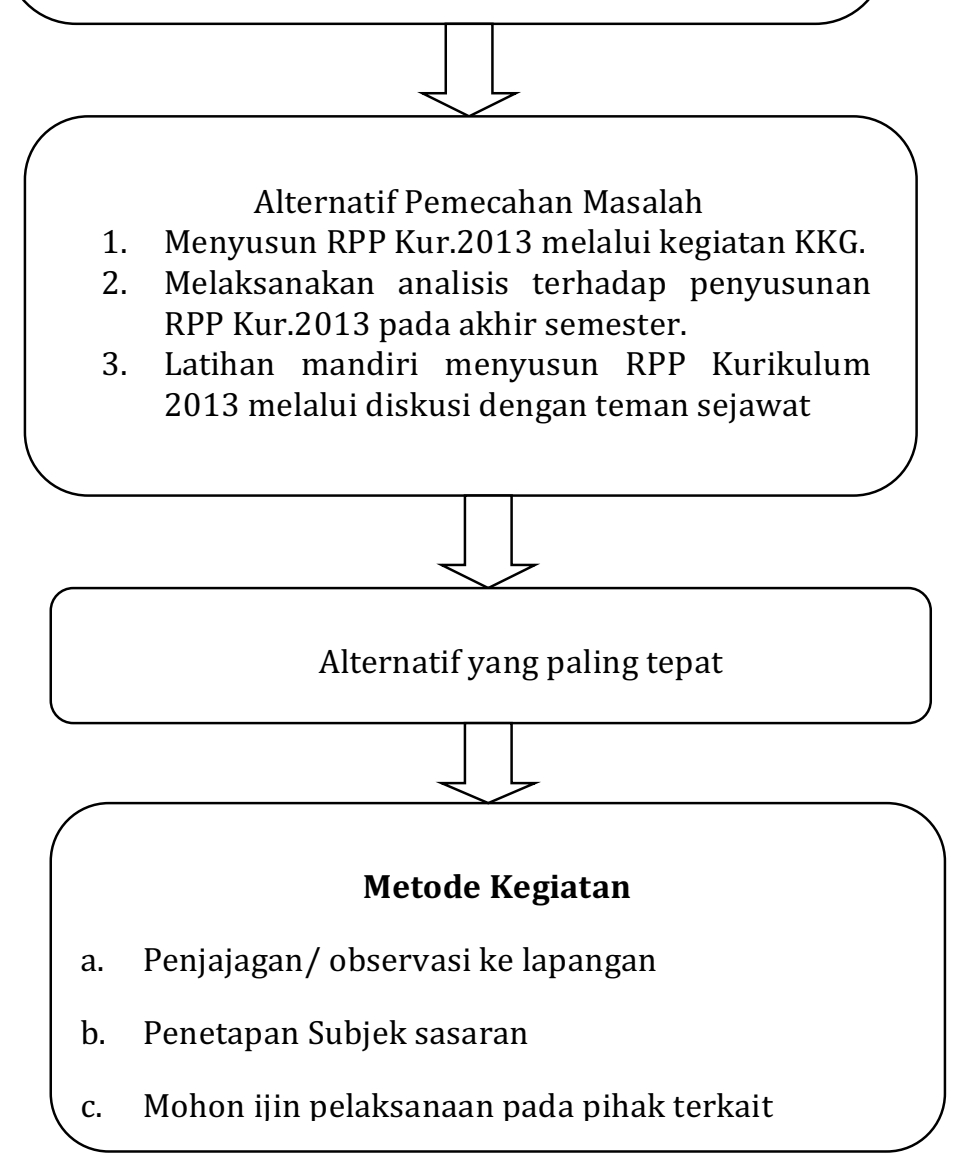

Gambar 1 Bagan Kerangka Pemecahan Masalah

Evaluasi kegiatan P2M ini dilihat dari dua aspek, yaitu (1) keterlibatan peserta dan (2) output kegiatan. Indikator keberhasilan kegiatan dilihat dari dua komponen evaluasi tersebut. Kegiatan P2M ini mentargetkan keterlibatan peserta minimal 42 orang guru yang berpartisipasi aktif dalam mengikuti seluruh rangkaian kegiatan. Output yang ditargetkan adalah dihasilkannya minimal 4 RPP tematik integratif dengan pendekatan saintifik.

\section{Hasil Dan Pembahasan}

\section{Hasil}

Peserta, Waktu dan Tempat Kegiatan

Kegiatan pokok yang dilakukan dimulai dari (1) persiapan materi pelatihan; (2) koordinasi tentang peserta pelatihan serta waktu dan tampat pelaksanaan kegiatan; dan (3) kegiatan pelatihan. Persiapan materi pelatihan dilakukan di Bulan Juli dan Agustus 2016. Pada persiapan materi dibuat makalah tentang cara penyusunan RPP tematik integratif pendekatan saintifik, pembuatan power point, dan menyediakan contoh-contoh RPP tematik SD kelas I, II, III, dan IV. Kegiatan koordinasi dengan calon peserta dan penetepan peserta, waktu dan tempat dilakukan pada pertengahan bulan Agustus 2016. Kegiatan pelatihan dilakukan pada Tanggal 20 Agustus 2016 yang dilaksanakan di Aula Gugus VIII Abiansemal (SD N 2 Sibangkaja). Jumlah peserta pelatihan adalah 42 orang. 


\section{Pelaksanaan Kegiatan}

Kegiatan pelatihan diawali dengan registrasi peserta. Dari 42 guru yang hadir, semua telah membawa RPP untuk digunakan dalam latihan. Ada 8 peserta membawa Laptop sehingga memudahkan dalam mengerjakan tugas kelompok.

Materi tentang penyusunan RPP tematik mengacu pada Permen Dikbud No. 65 Tahun 2013. Dalam pelatihan masih tampak ada variasi format RPP, namun secara prinsip masih tetap mengacu pada peraturan yang telah ditetapkan. Kegiatan dimulai dari presentasi oleh nara sumber pertama yang membawakan tentang prinsip-prinsip menyusun tematik integratif melalui pendekatan saintifik, setelah itu narasumber yang kedua membawakan materi tentang bagaimana menyusun RPP tematif integratif dengan pendekatan saintifik. Setelah itu dilakukan diskusi, para peserta mengajukan beberapa pertanyaan dan langsung dijawab oleh nara sumber. Setelah waktu makan siang berakhir seluruh peserta dibentuk menjadi 8 kelompok dengan jumlah kelompok 5-6 orang. Kelompok 1 dan 2 membuat RPP kelas I, kelompok 3 dan 4 membuat RPP kelas II, kelompok 5 dan 6 membuat RPP kelas III dan kelompok 7 dan 8 membuat RPP kelas IV.

Produk Pelatihan

Pada akhir dari kegiatan dan pelatihan, tekumpul 4 RPP Tematik Integratif (Kelas I, II, III, dan IV) yang telah disempurnakan.

\section{Pembahasan}

Kegiatan pelatihan penyusunan RPP tematik integratif melalui pendekatan saintifik bagi guru SD sangat relevan dengan kebutuhan guru seiring dengan tuntutan guru profesional. Guru sekarang ini dituntut untuk mampu berinovasi dalam merancang pembelajaran sesuai dengan tingkat perkembangan peserta didiknya. Secara umum, animo guru untuk mengikuti kegiatan ini tinggi. Namun karena keterbatasan dana, sebagian dari guru yang berminat sebagai peserta tidak bisa dilibatkan. Kegiatan pelatihan dapat terlaksana sesuai rencana akibat partisipasi aktif peserta serta dukungan sarana prasarana yang ada di Gugus VIII Abiansemal. Tugas untuk menyusun empat RPP tematik integratif melalui pendekatan saintifik dapat diselesaikan tepat waktu menunjukkan bahwa peserta sangat antusias dan berpartisipasi aktif dalam mengikuti pelatihan ini. Banyak tanggapan dan saran dari para peserta terhadap hasil kerja kelompok menunjukkan bahwa kegiatan pelatihan ini merupakan hal yang menarik dan dibutuhkan oleh peserta.

\section{Simpulan Dan Saran}

Kegiatan pengabdian masyarakat ini dapat meningkatkan pengetahuan dan kemampuan guru peserta dalam menyusun RPP tematik integratif melalui pendekatan saintifik. Peserta sangat antusias mengikuti pelatihan ini sehingga dapat menyelesaikan semua tugas yang diberikan selama pelatihan. Produk yang dihasilkan berupa 4 RPP tematik integratif melalui pendekatan saintifik. Dengan demikian, kegiatan ini secara real dapat membantu guru peserta untuk menyusun RPP tematik integratif melalui pendekatan saintifik di tempat tugasnya masing-masing.

\section{Daftar Pustaka}

Depdikbud. 2013. Kurikulum Tahun 2013. Jakarta: Depdikbud.

Depdikbud. 2013. Peraturan Menteri Pendidikan dan Kebudayaan No. 65 Tahun 2013 tentang Standar Proses Pendidikan Dasar dan Menengah. Jakarta: Depdikbud.

Depdiknas. 2005. Undang-undang Sistem Pendidikan Nasional. Jakarta. Depdiknas.

Depdiknas. 2005. Undang-undang No. 14 Tahun 2005 Tentang Profesionalisme Guru dan Dosen. Jakarta.: Depdiknas.

Depdiknas. 2005. Peraturan Menteri No. 19 Th 2005 Tentang Standar Nasional Pendidikan. Jakarta: BSNP Depdiknas.

Nurhadi, Agus Gerrads. 2003. Kontekstual dan Penerapannya dalam KBK. Malang: Universitas Negeri Malang. 